\title{
Conferences/Seminars
}

\section{The Seminar on the Impact of Islamic Lifestyles on the Health and Development of Mankind}

\author{
Amman, Jordan
}

Dhu al Qidah 19-22, 1409/June 23-26, 1989

The Eastern Mediterranean Regional Office of the World Health Organization, the Islamic Organization for Medical Sciences, and the Royal Academy for Islamic Civilization Research (the Aal Al-Bayt Foundation) jointly sponsored a seminar on "Islamic Lifestyles and their Impact on Health and the General Development of Mankind" in order to put this Islamic heritage in the service of all human beings.

The idea of holding this Seminar was first conceived by the Eastern Mediterranean Regional Office of the World Health Organization because of its profound conviction that:

1. Health constitutes the physical, psychological, and social wellbeing of the individual.

2. Particular lifestyles have a major impact on the health of the individual and the society at large.

3. Islam views the concept of well-being as a pre-requisite of Aqidah (creed) and Shariah which the Muslims fully applied and implemented in their Golden Age - thus, providing living proof of its success in real life.

The first task undertaken by the participants involved the exhaustive listing and description of Islamic lifestyles in all spheres, and, the determining of their Islamic roots on the basis of evidence from the Qur'an and Hadith. The second task focused on exploring the benefits to be acquired and the harms to be avoided through the adoption of these Islamic lifestyles by the individual, the family, the society, and all human beings especially in the spheres of mental and physical health, and the well-being of social and human relationships. The third task involved devising plans of action for utilizing and applying all or part of the knowledge gained about Islamic lifestyles in order to demonstrate their beneficial influence as a means of reforming life and setting mankind on the straight path.

The Seminar participants also formed a smaller committee to examine the results of its research and deliberations so as to prepare, as soon as possi- 
ble, a well-written and accurate bibliography and index based on the actual text of the Qur'an, the Sunnah, and the correct Hadiths.

The participants also recommended that there be continued cooperation between the Regional Office of the World Health Organization, the Islamic Organization for Medical Sciences, and the Royal Academy for Islamic Civilization Research (the Aal Al-Bayt Foundation) in order to follow up action in the field of exploring the Islamic teachings which fulfill the needs of mankind by guiding and directing mankind's efforts along the path of universal health in its broad sense, and which provide for mankind's highly integrated and indivisible material, psychological, and spiritual makeup. Furthermore, in order to apply and implement the knowledge gained during the Seminar's sessions, the participants issued a document entitled "The Amman Declaration for the Improvement of Health" (See appended text).

The participants also welcomed the proposed cooperation between the Regional Office of the World Health Organization, the Islamic Organization for Medical Sciences, the Royal Academy for Islamic Civilization Research (the Aal Al-Bayt Foundation), and the organizations whose representatives in the Seminar expressed a willingness and readiness for such cooperation - in particular, the Islamic Educational, Scientific, and Cultural Organization, the Nur Al-Hussain Foundation, the International Institute of Islamic Thought, the Jordanian Council of Islamic Organizations, and the Society for the Well-Being of Rheumatic Heart Disease Patients, the Arab Society for Islamic Education, the Islamic Center in Achen, the Muslim Student Federation in Europe, the Muslim Labor Union in Europe, and the International Islamic Society for Mental Health.

The participants also called upon all other interested organizations to cooperate in fulfilling the Seminar's objectives, and further recommended that the Regional Office of the World Health Organization coordinate the follow-up activity aimed at implementing the Seminar's recommendations and the Amman Declaration.

\section{The Amman Declaration for the Improvement of Health}

In order to realize universal health by the year 2000 , the Seminar on the Impact of Islamic Lifestyles on the Health and Development of Mankindmeeting in Amman, Jordan-issued the following declaration for the improvement of health:

This Seminar was held in order to meet the dire need, in the Eastern Mediterranean Region, to formulate Health Advisories for its inhabitants in a language they could understand pursuing health improvement by making 
use of the spiritual nature of its inhabitants whose religion constitutes a powerful driving force in their lives. The Seminar also gained its momentum from the deep-rooted health heritage which this region's inhabitants contributed to human civilization, as well as from the principles of the World Health Organization whose aim is the realization of universal health; the Alma Ata Declaration of Primary Health Care; and the Resolution of the International Health Society concerning the spiritual dimension.

\section{First:}

According to the Hadith, health is a gift from Allah of which many people are deprived.

\section{Second:}

As an element of life, health cannot be realized without the presence of the other main elements-e.g., freedom, security, justice, education, work, sufficiency, food, water, clothing, housing, marriage, and environmental protection.

\section{Third:}

As the Qur'an commands, man can safeguard his health by maintaining his health scale in a state of equilibrium-by neither transgressing nor adulterating.

\section{Fourth:}

As mentioned in the Hadith, in order to enjoy complete well-being, every person must maintain a health reserve from which to draw on during illness.

\section{Fifth:}

Every individual's lifestyle has a major impact on his health and well-being.

\section{Sixth:}

Islamic lifestyles have numerous positive elements for maintaining and improving health, as well as for prohibiting negative behavior detrimental to health.

\section{Seventh:}

As defined by the Qur'an, Islam is the religion of innate nature (Fitrah) with which Allah endowed mankind. Adopting and dedicating oneself to Islamic life-styles is a fulfillment of man's true nature in harmony with Allah's 
laws concerning the body, the mind, the individual, the family, the society, mankind, and the environment.

\section{Eighth:}

An inseparable document appended to this declaration provides a listing of the Islamic lifestyles derived from the Qur'an and the Sunnah which have a major impact on the improvement of health and the general development of mankind.

\section{Ninth:}

The Seminar participants call upon all international organizations, governments, and voluntary non-governmental organizations to promote and maintain health by encouraging positive lifestyles, particularly through the following:

1. defining the Islamic lifestyles which promote and maintain a healthy life, and calling for their adoption through channels appropriate for the circumstances of each country;

2 . providing the most favorable conditions for promoting and maintaining health and healthy lifestyles -without violating these conditions whether by publicizing lifestyles detrimental to health, producing materials that are harmful to health, or propagating unhealthy behavior;

3. promoting the comprehensive development of local societies, and helping them to realize their basic needs through selfdependence - this being a more practical approach aimed at the adoption of healthy lifestyles;

4. reorienting the institutions of health, education, culture, and information in a way that would promote health and encourage healthy lifestyles, especially those of the type mentioned in the appended document;

5. reorienting the institutions of health education so as to give a humanitarian character to health vocations by making them missions rather than professions; and

6. devoting a decade for strengthening efforts aimed at implementing a plan devised by the concerned bodies for the purpose of propagating Islamic lifestyles. 